\title{
Endothelin-1 in Congenital Heart Disease
}

\author{
MAURICE BEGHETTI, STEPHEN M. BLACK, AND JEFFREY R. FINEMAN \\ Pediatric Cardiology Unit [M.B.], Department of Pediatrics, Children's University Hospital, Geneva, \\ Switzerland; Department of Biomedical and Pharmaceutical Sciences [S.M.B.], University of Montana, \\ Missoula, MT, 59802; Department of Pediatrics, University of California, and the Cardiovascular \\ Research Institute [J.R.F.], San Francisco, CA, 94143
}

\begin{abstract}
ABST
Endothelin-1 (ET-1) is a 21-amino acid polypeptide pro-
duced primarily by vascular endothelial cells. First discovered in
1988 as a potent vasoconstrictor, it has subsequently been ap-
preciated to participate in several biologic activities, including
vascular smooth muscle proliferation, fibrosis, cardiac and vas-
cular hypertrophy, and inflammation. Increasing data demon-
strate alterations in ET-1 signaling in newborns, infants, and
children with congenital heart defects that are associated with
alterations in pulmonary blood flow. This review outlines the
pathophysiologic role of the ET-1 cascade in the development of
altered pulmonary vascular tone and reactivity that occurs with
\end{abstract}
congenital heart disease and its repair, following the use of cardiopulmonary bypass. In addition, therapeutic implications for the use of novel ET receptor antagonists will be emphasized. (Pediatr Res 57: 16R-20R, 2005)
Abbreviations
CPB, cardiopulmonary bypass
CHD, congenital heart defect
ET-1, endothelin 1,
PVR, pulmonary vascular resistance

ET-1 was originally isolated in 1988 as a 21 -amino acid polypeptide produced by pulmonary and systemic vascular endothelial cells, and was described as the most potent endogenous vasoconstrictor discovered to date (1). Subsequently it has been appreciated that ET-1 may be produced by a variety of cell types, and has numerous biologic properties within the cardiovascular, respiratory, renal, endocrine, gastrointestinal, and neurologic systems. These biologic properties include the regulation of vasomotor tone, vascular smooth muscle proliferation, fibrosis, cardiac and vascular hypertrophy, and inflammation (Fig. 1). In addition, alterations in the ET-1 cascade have been implicated in the pathophysiology of a variety of disease states, including congestive heart failure, bronchoconstriction, fibrotic disorders, and pulmonary hypertension (2-5). Increasing data demonstrate alterations in ET-1 signaling in newborns, infants, and children with congenital heart defects (CHD) that are associated with alterations in pulmonary blood flow (6-10). This review outlines the pathophysiologic role of the ET-1 cascade in the development of altered pulmonary vascular tone and reactivity that occurs with congenital heart disease and its repair, following the use of cardiopulmonary bypass (CPB). In addition, therapeutic implications for the use of novel ET receptor antagonists will be emphasized.

Received September 13, 2004; accepted January 3, 2005.

Correspondence: Maurice Beghetti, M.D., Pediatric Cardiology Unit, Hôpital des Enfants, 1211 Genève 14, Switzerland; E-mail: Maurice.Beghetti@hcuge.ch

This research was supported by grants HL61284 (J.R.F.), HL 60190 and HL67841 (S.M.B.), and an educational grant by Actelion Inc.

\section{THE ENDOTHELIN CASCADE}

The gene for human ET-1 is located on chromosome 6 and is translated to a 203 -amino acid peptide precursor (preproET1 ), which is then cleaved to form proendothelin-1. Proendothelin, big ET-1, is then cleaved by a membrane-bound metalloprotein converting enzyme (Endothelin Converting Enzyme-1, ECE-1) into its functional form $(2,3,5,11)$. The biologic effects of ET-1 are mediated by at least two distinctive receptor populations, $\mathrm{ET}_{\mathrm{A}}$ and $\mathrm{ET}_{\mathrm{B}}$, the densities of which are different depending on age, species, pathologic state, and vascular bed studied. The $\mathrm{ET}_{\mathrm{A}}$ receptors are located on vascular smooth muscle cells and mediate vasoconstriction via phospholipase activation, the hydrolysis of phosphoinositol to inositol 1,4,5-triphosphate and diacylglycerol, and the subsequent release of $\mathrm{Ca}^{2+} . \mathrm{ET}_{\mathrm{A}}$ receptors also mediate smooth muscle cell proliferation, fibrosis, and inflammation. $\mathrm{The}_{\mathrm{ET}}$ receptors are located on endothelial cells and mediate vasodilation via the release of $\mathrm{NO}$ and potassium channel activation. $\mathrm{ET}_{\mathrm{B}}$ receptors also mediate the pulmonary clearance of circulating ET-1 (12-15). A second, less well-characterized subpopulation of $\mathrm{ET}_{\mathrm{B}}$ receptors is located on smooth muscle cells and mediate similar activities as the smooth muscle cell $\mathrm{ET}_{\mathrm{A}}$ receptors (15). In vivo animal studies demonstrate that the predominant hemodynamic effect of exogenous ET-1 in the young healthy pulmonary circulation is $\mathrm{ET}_{\mathrm{B}}$ receptor mediated vasodilation, with a developmental change to $\mathrm{ET}_{\mathrm{A}}$ receptor mediated vasoconstriction with increasing age (16). In addition to endothelial 


\section{Pathological roles of ET:}

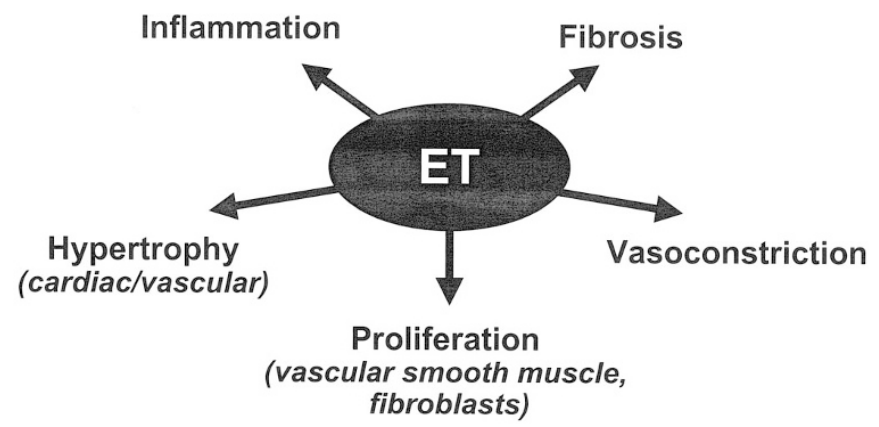

Figure 1. Endothelin-1 has been implicated in the pathology of several biologic conditions beyond its very potent vasoconstricting effects. These include proliferation, hypertrophy, fibrosis, inflammation, and hypertrophy.

cell production, ET-1 production has been demonstrated in a variety of cell types within the lung, including vascular and airway smooth muscle cells and airway epithelial cells (3). Lastly, ET-1 is produced within the myocardium, and may have important effects of myocardial growth and function (17). However, data are extremely limited on the role of ET-1 in the myocardial alterations associated with CHD. Therefore, the focus of this review will be the role of ET-1 on the pulmonary vasculature.

\section{ET-1 AND PULMONARY HYPERTENSION SECONDARY TO CHD}

The development of pulmonary hypertension and its associated increased vascular reactivity, commonly accompanies CHD with increased pulmonary blood flow or increased pulmonary venous pressure (18-20). After surgical correction, early vascular changes are reversible; however, more severe changes are irreversible and progressive. Early surgical repair of these CHD has decreased the incidence of irreversible pulmonary vascular disease. However, even children with reversible vascular changes may suffer significant morbidity and mortality in the peri- and postoperative periods secondary to both chronic and acute elevations in pulmonary vascular resistance (PVR) (18). In addition, mild elevations in PVR in infants with single ventricle physiology, may eliminate certain surgical options (i.e., Caval-pulmonary anastamosis and Fontan procedures) (21). Therefore, the status of the pulmonary vasculature is often the principal determinant of the clinical course and feasibility of surgical treatment.

Increasing evidence suggests that endothelial dysfunction, secondary to the altered mechanical forces associated with CHD participate in the development and maintenance of pulmonary hypertension and its associated increased vascular reactivity. In particular, the data on ET-1 is compelling. For example, several human studies demonstrate markedly elevated plasma ET-1 levels in children with CHD and increased pulmonary blood flow (6-10). Less consistently, some studies have demonstrated a positive correlation between the level of
ET-1 and the degree of pulmonary hypertension, and other studies have demonstrated a net increase in ET-1 levels across the lung, suggesting pulmonary ET-1 production in those patients with pulmonary hypertension $(6,9,10)$. A recent study in children with normal pulmonary vascular resistance, demonstrated a correlation between mean pulmonary arterial pressure and plasma ET-1 levels, yet no correlation with pulmonary blood flow (22). These data, and preliminary in vitro data, suggest that the primary mechanical force that up-regulates ET-1 is pressure, but not flow (23). It is interesting to speculate a role for ET-1 in the higher incidence of pulmonary hypertension secondary to high pressure, high flow congenital heart defects (ventricular septal defects), as opposed to low pressure, high flow defects (atrial septal defects). Additional human data are derived from patients with advanced pulmonary vascular disease undergoing transplantation. For example, Giaid et al. demonstrated an increase in preproET-1 gene expression in those patients with advanced secondary pulmonary hypertension, with a subset of these being secondary to CHD (24).

To better characterize early and sequential alterations in ET-1 signaling secondary to CHD, a lamb model of CHD utilizing fetal aortopulmonary graft placement has been investigated. Postnatally, these lambs (shunt lambs) have a pulmonary to systemic blood flow ratio of approximately $2: 1$, a mean pulmonary arterial pressure that is $50-75 \%$ of mean systemic arterial pressure, and pulmonary vascular remodeling characteristic of children with pulmonary hypertension and increased pulmonary blood flow (25). Upon initial evaluation at $1 \mathrm{wk}$ of age, peripheral lung tissue concentrations of ET-1 were increased by greater than 4 -fold in shunt lambs, compared with age or twin match controls (26). Subsequent evaluations in lambs at 4 and 8 wk of age, demonstrate a persistent increase in both plasma and lung tissue ET-1 levels in shunt lambs (27-29). The increase in ET-1 levels was not associated with an increase in preproET-1 protein or mRNA levels, but was associated with significant increases in ECE-1 protein and mRNA. These data suggest that the increase in ET-1 levels associated with increased pulmonary blood flow is secondary to an up-regulation of ECE-1 following exposure to these associated mechanical forces.

The hemodynamic effect of exogenous ET-1 was also altered over time, and this was associated with altered ET receptor gene expression. In normal one-week-old lambs, exogenous ET-1 induced pulmonary vasodilation, which was replicated by the administration of 4-Ala-ET-1, an $\mathrm{ET}_{\mathrm{B}}$ receptor agonist, suggesting $\mathrm{ET}_{\mathrm{B}}$ receptor-mediated vasodilation. However, in one-week-old shunt lambs, the pulmonary vasodilating effect of both exogenous ET-1 and 4-Ala-ET-1 was lost. This was associated with a decrease in $\mathrm{ET}_{\mathrm{B}}$ receptor protein levels in shunt lambs. $\mathrm{ET}_{\mathrm{A}}$ receptor protein levels were unchanged in one-week-old shunt lambs (26). However, in 4-wk-old shunt lambs, $\mathrm{ET}_{\mathrm{A}}$ receptor protein and mRNA levels were increased. This was associated with ET-1-induced pulmonary vasoconstriction. 4-Ala-ET-1 had no effect in 4-wk-old shunt lambs, coinciding with a continued decrease in $\mathrm{ET}_{\mathrm{B}}$ receptor protein and mRNA $(27,28)$. Interestingly, both ET-1 and 4-Ala-ET-1 induced potent pulmonary vasoconstriction in 8-wk-old shunt lambs. This was associated with a continued 
increase in $\mathrm{ET}_{\mathrm{A}}$ receptor protein and a new increase in $\mathrm{ET}_{\mathrm{B}}$ receptor protein levels. Immunohistochemistry demonstrated that the up-regulation of $\mathrm{ET}_{\mathrm{B}}$ receptors coincided with a shift from an endothelial localization at $4 \mathrm{wk}$ to a predominant smooth muscle cell location in remodeled pulmonary vessels at $8 \mathrm{wk}$, suggesting the emergence of smooth muscle localized $\mathrm{ET}_{\mathrm{B}}$ receptors which mediate pulmonary vasoconstriction (29) (Fig. 2). These novel findings suggest an increasingly important role for both $\mathrm{ET}_{\mathrm{A}}$ and $\mathrm{ET}_{\mathrm{B}}$ receptors in the pathophysiology of pulmonary hypertension secondary to CHD. These findings correlate with a recent report demonstrating an upregulation of smooth muscle cell $\mathrm{ET}_{\mathrm{B}}$ receptor gene expression in patients with advanced pulmonary hypertension secondary to thromboembolic disease (30). In fact, in a postnatal piglet model of increased pulmonary blood flow that used an anastomosis between the subclavian artery and pulmonary artery, whole lung $\mathrm{ET}_{\mathrm{B}}$ receptor mRNA was increased, although localization studies were not performed (31). However, bosentan, a combined $\mathrm{ET}_{\mathrm{A}}$ and $\mathrm{ET}_{\mathrm{B}}$ receptor antagonist, completely blocked the physiologic and morphologic development of pulmonary hypertension in this model (31). Currently, there are ongoing multi-centered studies on the use of ET receptor antagonists in patients with advanced pulmonary vascular disease and Eisenmenger's physiology. Preliminary reports suggest both physiologic and functional improvement without worsening hypoxemia (personal communications).

Taken together, these data suggest an important role for the ET-1 cascade in the pathophysiology of pulmonary hypertension secondary to CHD. The potential role of the ETA versus

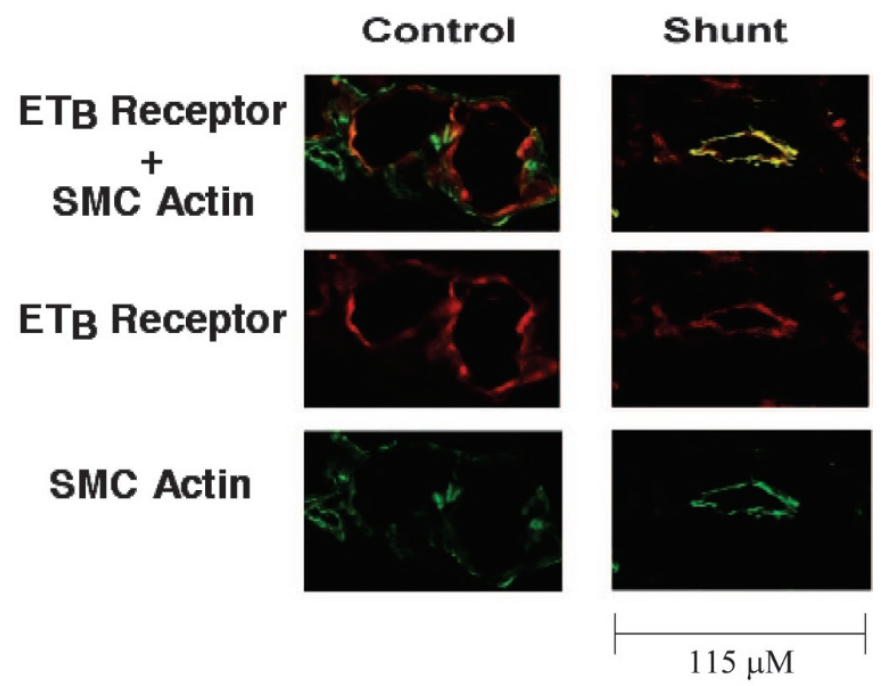

Figure 2. $\mathrm{ET}_{\mathrm{A}}$ and $\mathrm{ET}_{\mathrm{B}}$ protein expression in the lung in vivo from tissue from 8-week-old lambs. Immunohistochemical localization of $\mathrm{ET}_{\mathrm{A}}$ and $\mathrm{ET}_{\mathrm{B}}$ protein expression in the lung in vivo from 8-wk-old $(\mathrm{E}-\mathrm{H})$ lambs. Polyclonal rabbit $\mathrm{ET}_{\mathrm{A}}$ and $\mathrm{ET}_{\mathrm{B}}$ receptor antibodies and monoclonal mouse anti-SMC-actin antibodies were used to localize expression. $\mathrm{ET}_{\mathrm{A}}$ and $\mathrm{ET}_{\mathrm{B}}$ protein expression is shown in red while SMC-actin expression is shown in green. Co-localization is shown in yellow. Magnification is $800 \mathrm{X}$. In both shunt and control lambs, $\mathrm{ET}_{\mathrm{A}}$ receptors localize to smooth muscle cells in both shunt and control lambs. In eight-week control lambs, $\mathrm{ET}_{\mathrm{B}}$ receptors localize to endothelial cells. However in shunt lambs, sub-populations of $\mathrm{ET}_{\mathrm{B}}$ receptors localize to smooth muscle cells. Results are representative of 3 different sets of twin matches (control and shunt). Adapted from Circulation, 108:1646-1654, (C) 2003 American Heart Association, Inc., with permission. the ETB receptor in this disorder requires further investigation. This is particularly relevant in the early neonatal period, in which the potential benefits of the endothelial ETB receptor (vasodilation) versus the pathology of the smooth muscle cell ETB receptor (vasoconstriction and smooth muscle cell proliferation) has not been adequately investigated.

\section{ET-1 AFTER CARDIAC SURGERY FOR CONGENITAL HEART DISEASE}

Cardiopulmonary bypass is generally used to perform surgical correction of CHD. Cardiopulmonary bypass and related ischemia reperfusion injury results in generalized endothelial cell injury. Both histologic and functional endothelial cell abnormalities have been well documented in many tissues following ischemia reperfusion, including the myocardium, lung, brain, liver, kidneys, bowel, and pulmonary and systemic vascular smooth muscle (32-34).

There are compelling animal and human data demonstrating that ET-1 plays a significant role in the pathophysiology of ischemia-reperfusion injury. In particular, ET-1 levels are significantly increased in humans and animals during a variety of models of ischemia-reperfusion injury, including hypothermic CPB (35-39). In ischemia reperfusion, it has been shown that ET-1 becomes dominant whereas the production of NO becomes impaired and this imbalance contributes to ischemia reperfusion injury. Furthermore, CPB increases not only the production of ET-1 but also the expression of ET receptors especially in the lungs.

During CPB, ischemia-reperfusion injury to the heart is well documented and felt to be a major cause of postbypass low cardiac output syndrome. Both systolic and diastolic myocardial dysfunction are clearly demonstrated in adults and children following CPB. The pathophysiology is multi-factorial and includes both myocardial cell and endothelial cell damage. Myocardial histology demonstrates interstitial and cellular edema, apoptosis, and necrosis. Endothelial cell imaging also reveals swelling and necrosis of coronary vascular endothelial cells, and functional studies demonstrate the loss of endothelium-dependent relaxation, and secretion of ET-1. These changes result in depressed myocardial function, and decreased microcirculatory coronary blood flow and reserve (38).

Both endogenous and exogenous ET-1 produce very potent constriction of the coronary vasculature $(38,40)$. In addition, ET-1 has been shown to exert a positive inotropic effect on isolated ventricular myocytes (41). The inotropic effect is associated with prolongation of the action potential in the ventricular myocardium, which may explain the proarrhythmic effect of ET-1. However, despite the direct positive inotropic effect of ET-1 on myocytes, the administration of ET-1 decreases myocardial function and output as a result of myocardial ischemia secondary to its potent coronary vasoconstricting effects. Increased plasma and myocardial ET-1 levels have been demonstrated in animals and humans with several different cardiovascular disorders, which include atherosclerosis, myocardial ischemia and congestive heart failure $(38,40)$. During myocardial ischemia-reperfusion injury, increased myocardial production and release of ET-1, as well as an 
enhanced coronary constrictor response to ET-1, have been demonstrated. In addition, the majority of studies with endothelin receptor antagonists have shown a reduction of the ischemia-reperfusion myocardial injury $(38,42)$.

Although several studies have demonstrated increased plasma ET-1 levels during and after CPB, few studies have directly investigated the effects of ET- 1 and post- cardiopulmonary bypass myocardial dysfunction. In lambs with increased pulmonary blood flow secondary to in utero placement of aortopulmonary vascular grafts, both $\mathrm{ET}_{\mathrm{A}}$ selective and dual endothelin receptor antagonists completely attenuate the normal decrease in cardiac output following hypothermic CPB $(43,44)$. In addition, in a piglet model of hypothermic CPB, pretreatment with bosentan, an oral dual endothelin receptor antagonist, improved both right and left ventricular function, decreased leukocyte-mediated myocardial injury, and decreased cardiac cell death (35). Collectively, these data suggest that endogenous ET-1 is of pathophysiological importance in the decreased myocardial function following CPB, and that endothelin receptor antagonists may attenuate the injury and improve postbypass myocardial function.

Lung injury following CPB is also well described. Clinically, it is manifested as reduced oxygenation, reduced lung compliance and, most importantly, increased PVR and augmented pulmonary vascular reactivity, a known cause of morbidity and mortality after repair of CHD (33). This may result in decreased oxygen delivery, right ventricular dysfunction, and acute life-threatening increases in PVR, all of which contribute to the development of low cardiac output syndrome. The etiology of bypass-induced lung injury is multi-factorial, and includes complement activation, neutrophil accumulation, and oxygen free radical injury (45). However, injury to the pulmonary vascular endothelium, and its associated alterations in ET-1, is considered to be a major factor. In fact, patients with preexisting pulmonary vascular endothelial dysfunction are at greatest risk of developing clinically significant bypassinduced lung injury and low cardiac output syndrome.

As previously mentioned, compelling animal and human data suggest that alterations in ET-1 and ET receptors localization and expression secondary to endothelial injury contribute to the development of pulmonary arterial hypertension and its associated increased vascular reactivity $(6-8,24,46)$. During $\mathrm{CPB}$, several factors including the disruption of normal pulmonary blood flow $(36,37)$, complement activation, neutrophil activation, surgical stress, hypothermia, and alveolar hypoxia, induce further pulmonary vascular endothelial dysfunction and ET-1 production (37). In several animal and human studies, plasma ET-1 concentrations are consistently increased during and following CPB $(36,43,44)$. In piglets, this was associated with increased endothelin gene expression and receptors. In a study of children with CHD, the plasma concentration of ET-1 $3 \mathrm{~h}$ after CPB correlated with the degree of post- cardiopulmonary bypass pulmonary arterial hypertension, suggesting a role for ET-1 in the pathophysiology of postcardiopulmonary bypass pulmonary arterial hypertension (37). In addition, several animal studies suggest that treatment with endothelin receptor antagonists attenuates post- cardiopulmonary bypass pulmonary arterial hypertension and associated altered reactivity. Thus, in lambs with preexisting pulmonary arterial hypertension secondary to increased pulmonary blood flow, the increase in PVR following cardiopulmonary bypass was completely blocked when pretreated with either dual or $\mathrm{ET}_{\mathrm{A}}$-selective antagonists. In addition, the augmented pulmonary vascular reactivity following $\mathrm{CPB}$, which is responsible for the potential life-threatening acute increases in PVR, was also completely blocked in those lambs pretreated with endothelin receptor antagonists $(43,44)$. Similarly, in normal pigs and piglets, blockade with bosentan not only attenuated the increase in PVR following CPB, but also improved pulmonary function and decreased leukocyte-mediated lung injury $(35,36)$. Lastly, in children with congenital heart disease, a 20 min infusion of BQ 123, an ETA-selective antagonist, decreased pulmonary vascular resistance following surgical repair with the use of CPB (47).

Taken together, animal and human data suggest a role for ET-1 in the pathophysiology of lung dysfunction following CPB. In addition, these data suggest that pretreatment with endothelin receptor antagonists will prevent $\mathrm{CPB}$-induced pulmonary dysfunction. This should result in decreased PVR, improved right ventricular function, decreased incidence of postbypass pulmonary hypertensive crises, and improved pulmonary compliance and oxygenation. The end result should be an improvement in oxygen delivery and a subsequent decrease in the incidence of postbypass low cardiac output syndrome.

Injury to the brain, kidneys, and liver are well demonstrated in both children and adults following hypothermic CPB (21). Individually, these injuries contribute to significant comorbidity and mortality in these patients. In particular, neurologic sequelae from cardiopulmonary bypass -induced brain injury are a prominent factor in the long-term outcome of children, and their recognition and prevention is a major focus of ongoing investigation (21). In addition, the metabolic derangements that result from these organ injuries alter cardiopulmonary function, and contribute to the development of low cardiac output syndrome. Experimental models of organ injury suggest that ET-1 levels are increased during ischemic injury to the brain, kidneys and liver. Investigations utilizing endothelin receptor antagonists have shown a reduction in the ischemic injury, suggesting a pathophysiological role for ET-1 in these injuries $(48-50)$.

In summary, there is compelling human and animal data to suggest a role for ET- 1 in the pathophysiology of pulmonary hypertension secondary to CHD, and the alterations in pulmonary vascular tone and reactivity following the use of CPB. Additionally, evidence suggests a role for ET-1 in the pathophysiology of ischemia-reperfusion injury of several organs associated with cardiopulmonary bypass. The exact role of $\mathrm{ET}_{\mathrm{A}}$ and $\mathrm{ET}_{\mathrm{B}}$ receptors in these processes remains to be better elucidated. The smooth muscle cell $\mathrm{ET}_{\mathrm{B}}$ receptor is known to be an inducible receptor, which is up-regulated in pathologic conditions. In contrast the endothelial $\mathrm{ET}_{\mathrm{B}}$ receptor is downregulated in pathologic situations, thus the potential vasodilating effect of $\mathrm{ET}_{\mathrm{B}}$ may be disrupted and directed to proliferation, inflammation and vasoconstriction. With the recent development of ET receptor antagonists as potential therapeutic agents, these data suggest that the investigation of ET 
receptor antagonists for the treatment of both chronic and acute pulmonary hypertension secondary to CHD is warranted. Although preliminary data suggest a role for dual receptor blockade, a better understanding of the receptor alterations in CHD and $\mathrm{CPB}$ ischemia reperfusion injury will be important, particularly in the neonatal period, to define the optimal use of selective $\mathrm{ET}_{\mathrm{A}}$ receptor antagonists versus dual ET receptor antagonists in these settings. (16,22,23).

\section{REFERENCES}

1. Yanagisawa M, Kurihara H, Kimura S, Tomobe Y, Kobayashi M, Mitsui Y, Yazaki Y, Goto K, Masaki T 1988 A novel potent vasoconstrictor peptide produced by vascular endothelial cells. Nature 332:411-415

2. La M, Reid JJ 1995 Endothelin-1 and the regulation of vascular tone. Clin Exp Pharmacol Physiol 22:315-323

3. Fagan KA, McMurtry IF, Rodman DM 2001 Role of endothelin-1 in lung disease. Respir Res 2:90-101

4. Clozel M 2003 Effects of bosentan on cellular processes involved in pulmonary arterial hypertension: do they explain the long-term benefit? Ann Med 35:605-613

5. Galie N, Manes A, Branzi A 2004 The endothelin system in pulmonary arterial hypertension. Cardiovasc Res 61:227-237

6. Yoshibayashi M, Nishioka K, Nakao K, Saito Y, Matsumura M, Ueda T, Temma S, Shirakami G, Imura H, Mikawa H 1991 Plasma endothelin concentrations in patients with pulmonary hypertension associated with congenital heart defects. Evidence for increased production of endothelin in pulmonary circulation. Circulation 84:2280-2285

7. Vincent JA, Ross RD, Kassab J, Hsu JM, Pinsky WW 1993 Relation of elevated plasma endothelin in congenital heart disease to increased pulmonary blood flow. Am J Cardiol 71:1204-1207

8. Allen SW, Chatfield BA, Koppenhafer SA, Schaffer MS, Wolfe RR, Abman SH 1993 Circulating immunoreactive endothelin-1 in children with pulmonary hypertension. Association with acute hypoxic pulmonary vasoreactivity. Am Rev Respir Dis 148:519-522

9. Tutar HE, Imamoglu A, Atalay S, Gumus H, Akar N 1999 Plasma endothelin-1 levels in patients with left-to-right shunt with or without pulmonary hypertension. Int J Cardiol 70:57-62

10. Ishikawa S, Miyauchi T, Ueno H, Ushinohama H, Sagawa K, Fusazaki N, Sunagawa H, Honda S, Sakai S, Yamaguchi I, et al 1995 Influence of pulmonary blood pressure and flow on endothelin-1 production in humans. J Cardiovasc Pharmacol 26(Suppl 3):S429-S433

11. Shimada K, Takahashi M, Ikeda M, Tanzawa K 1995 Identification and characterization of two isoforms of an endothelin-converting enzyme-1. FEBS Lett 371:140144

12. Arai H, Hori S, Aramori I, Ohkubo H, Nakanishi S 1990 Cloning and expression of a cDNA encoding an endothelin receptor. Nature 348:730-732

13. Sakurai T, Yanagisawa M, Takuwa Y, Miyazaki H, Kimura S, Goto K, Masaki T 1990 Cloning of a cDNA encoding a non-isopeptide-selective subtype of the endothelin receptor. Nature 348:732-735

14. Wong J, Vanderford PA, Winters J, Soifer SJ, Fineman JR 1995 Endothelinb receptor agonists produce pulmonary vasodilation in intact newborn lambs with pulmonary hypertension. J Cardiovasc Pharmacol 25:207-215

15. Shetty SS, Okada T, Webb RL, DelGrande D, Lappe RW 1993 Functionally distinct endothelin B receptors in vascular endothelium and smooth muscle. Biochem Biophys Res Commun 191:459-464

16. Wong J, Vanderford PA, Fineman JR, Soifer SJ 1994 Developmental effects of endothelin-1 on the pulmonary circulation in sheep. Pediatr Res 36:394-401

17. Ruwhof C, van der Laarse A 2000 Mechanical stress-induced cardiac hypertrophy: mechanisms and signal transduction pathways. Cardiovasc Res 47:23-37

18. Burrows FA, Klinck JR, Rabinovitch M, Bohn DJ 1986 Pulmonary hypertension in children: perioperative management. Can Anaesth Soc J 33:606-628

19. Hoffman JI, Rudolph AM, Heymann MA 1981 Pulmonary vascular disease with congenital heart lesions: pathologic features and causes. Circulation 64:873-877

20. Wheller J, George BL, Mulder DG, Jarmakani JM 1979 Diagnosis and management of postoperative pulmonary hypertensive crisis. Circulation: 60:1640-1644

21. Castaneda AR, Jonas RA, JE M, FL H 1994 Cardiopulmonary bypass, hypothermia and circulatory arrest. In: AR C (ed) Cardiac Surgery of the Neonate and infant. WB Saunders Company, Philadelphia, pp 23-40

22. Fratz S, Geiger R, Kresse H, Roemer G, Hennig M, Sebening W, Hess J 2003 Pulmonary blood pressure, not flow, is associated with net endothelin-1 production in the lungs of patients with congenital heart disease and normal pulmonary vascular resistance. J Thorac Cardiovasc Surg 126:1724-1729

23. Dschietzig T, Richter C, Bartsch C, Bohme C, Heinze D, Ott F, Zartnack F, Baumann G, Stangl K 2001 Flow-induced pressure differentially regulates endothelin-1, urotensin II, adrenomedullin, and relaxin in pulmonary vascular endothelium. Biochem Biophys Res Commun 289:245-251

24. Giaid A, Yanagisawa M, Langleben D, Michel RP, Levy R, Shennib H, Kimura S, Masaki T, Duguid WP, Stewart DJ 1993 Expression of endothelin-1 in the lungs of patients with pulmonary hypertension. N Engl J Med 328:1732-1739
25. Reddy VM, Meyrick B, Wong J, Khoor A, Liddicoat JR, Hanley FL, Fineman JR 1995 In utero placement of aortopulmonary shunts. A model of postnatal pulmonary hypertension with increased pulmonary blood flow in lambs. Circulation 92:606-613 26. Ovadia B, Reinhartz O, Fitzgerald R, Bekker JM, Johengen MJ, Azakie A, Thelitz S, Black SM, Fineman JR 2003 Alterations in ET-1, not nitric oxide, in 1-week-old lambs with increased pulmonary blood flow. Am J Physiol Heart Circ Physio 284:H480-H490

27. Wong J, Reddy VM, Hendricks-Munoz K, Liddicoat JR, Gerrets R, Fineman JR 1995 Endothelin-1 vasoactive responses in lambs with pulmonary hypertension and increased pulmonary blood flow. Am J Physiol 269:H1965-1972

28. Black SM, Bekker JM, Johengen MJ, Parry AJ, Soifer SJ, Fineman JR 2000 Altered regulation of the ET-1 cascade in lambs with increased pulmonary blood flow and pulmonary hypertension. Pediatr Res 47:97-106

29. Black SM, Mata-Greenwood E, Dettman RW, Ovadia B, Fitzgerald RK, Reinhartz O, Thelitz S, Steinhorn RH, Gerrets R, Hendricks-Munoz K, Ross GA, Bekker JM, Johengen MJ, Fineman JR 2003 Emergence of smooth muscle cell endothelin B-mediated vasoconstriction in lambs with experimental congenital heart disease and increased pulmonary blood flow. Circulation 108:1646-1654

30. Bauer M, Wilkens H, Langer F, Schneider SO, Lausberg H, Schafers HJ 2002 Selective upregulation of endothelin B receptor gene expression in severe pulmonary hypertension. Circulation 105:1034-1036

31. Rondelet B, Kerbaul F, Motte S, van Beneden R, Remmelink M, Brimioulle S, McEntee K, Wauthy P, Salmon I, Ketelslegers JM, Naeije R 2003 Bosentan for the prevention of overcirculation-induced experimental pulmonary arterial hypertension. Circulation 107:1329-1335

32. Wessel DL, Adatia I, Giglia TM, Thompson JE, Kulik TJ 1993 Use of inhaled nitric oxide and acetylcholine in the evaluation of pulmonary hypertension and endothelial function after cardiopulmonary bypass. Circulation 88:2128-2138

33. Shafique T, Johnson RG, Dai HB, Weintraub RM, Sellke FW 1993 Altered pulmonary microvascular reactivity after total cardiopulmonary bypass. J Thorac Cardiovasc Surg 106:479-486

34. Turner-Gomes SO, Andrew M, Coles J, Trusler GA, Williams WG, Rabinovitch M 1992 Abnormalities in von Willebrand factor and antithrombin III after cardiopulmonary bypass operations for congenital heart disease. J Thorac Cardiovasc Surg 103:87-97

35. Pearl JM, Wellmann SA, McNamara JL, Lombardi JP, Wagner CJ, Raake JL, Nelson DP 1999 Bosentan prevents hypoxia-reoxygenation-induced pulmonary hypertension and improves pulmonary function. Ann Thorac Surg 68:1714-1721; discussion $1721-1722$

36. Carteaux JP, Roux S, Siaghy M, Schjoth B, Dolofon P, Bechamps Y, Mertes PM, Villemot JP 1999 Acute pulmonary hypertension after cardiopulmonary bypass in pig: the role of endogenous endothelin. Eur J Cardiothorac Surg 15:346-352

37. Komai H, Adatia IT, Elliott MJ, de Leval MR, Haworth SG 1993 Increased plasma levels of endothelin-1 after cardiopulmonary bypass in patients with pulmonary hypertension and congenital heart disease. J Thorac Cardiovasc Surg 106:473-478

38. Pernow J, Wang QD 1997 Endothelin in myocardial ischaemia and reperfusion. Cardiovasc Res 33:518-526

39. Huang H, Yao T, Wang W, Zhu D, Zhang W, Chen H, Fu W 2003 Continuous ultrafiltration attenuates the pulmonary injury that follows open heart surgery with cardiopulmonary bypass. Ann Thoracic Surg 76:136-140

40. Roux S, Breu V, Ertel SI, Clozel M 1999 Endothelin antagonism with bosentan: a review of potential applications. J Mol Med 77:364-376

41. Takanashi M, Endoh M 1991 Characterization of positive inotropic effect of endothelin on mammalian ventricular myocardium. Am J Physiol 261:H611-H619

42. Pearl JM, Nelson DP, Wagner CJ, Lombardi JP, Duffy JY 2001 Endothelin receptor blockade reduces ventricular dysfunction and injury after reoxygenation. Ann Thorac Surg 72:565-570

43. Reddy VM, Hendricks-Munoz KD, Rajasinghe HA, Petrossian E, Hanley FL, Fineman JR 1997 Post-cardiopulmonary bypass pulmonary hypertension in lambs with increased pulmonary blood flow. A role for endothelin 1. Circulation 95:1054-1061

44. Petrossian E, Parry AJ, Reddy VM, Akkersdijk GP, McMullan DM, Thompson L, Hendricks-Munoz KD, Hallak H, Hanley FL, Fineman JR 1999 Endothelin receptor blockade prevents the rise in pulmonary vascular resistance after cardiopulmonary bypass in lambs with increased pulmonary blood flow. J Thorac Cardiovasc Surg $117: 314-323$

45. Chenoweth DE, Cooper SW, Hugli TE, Stewart RW, Blackstone EH, Kirklin JW 1981 Complement activation during cardiopulmonary bypass: evidence for generation of C3a and C5a anaphylatoxins. N Engl J Med 304:497-503

46. Miyauchi T, Yorikane R, Sakai S, Sakurai T, Okada M, Nishikibe M, Yano M, Yamaguchi I, Sugishita Y, Goto K 1993 Contribution of endogenous endothelin-1 to the progression of cardiopulmonary alterations in rats with monocrotaline-induced pulmonary hypertension. Circ Res 73:887-897

47. Schulz-Neick I, Li J, Reader JA, Shekerdemian L, Redington AN, Penny DJ 2002 The endothelin antagonist BQ 123 reduces pulmonary vascular resistance after surgical intervention for congenital heart disease. J Thorac Cardiovasc Surg 124:435-441

48. Greenberg DA, Chan J, Sampson HA 1992 Endothelins and the nervous system. Neurology 42:25-31

49. Simonson MS, Dunn MJ 1993 Endothelin peptides and the kidney. Annu Rev Physiol 55:249-265

50. Ricciardi R, Schaffer BK, Shah SA, Quarfordt SH, Banner BF, Wheeler SM, Donohue SE, Meyers WC, Chari RS 2001 Bosentan, an endothelin antagonist, augments hepatic graft function by reducing graft circulatory impairment following ischemia/reperfusion injury. J Gastrointest Surg 5:322-329 